\title{
"ORANG KAMPUNG", PEMASARAN DIGITAL, DAN KEBIJAKAN PUBLIK: SEBUAH TINJAUAN DAN AGENDA PENELITIAN. STUDI KASUS : PEMASARAN TRADISIONAL SONGKO RECCA
}

\author{
Rulinawaty ${ }^{1)}$, Risnashari²), Ranak Lince ${ }^{3}$ \\ 1)Program Studi Administrasi Publik, FHISIP, Universitas Terbuka, Indoneisa \\ 2)Program Studi Manajemen, Fakultas Ekonomi, Universitas Terbuka, Indonesia \\ 3)Program Studi Pendidikan Matematika, FKIP, Universitas Terbuka, Indonesia \\ Coresponding Author : Rulinawaty \\ E-mail: ruly@ecampus.ut.ac.id
}

Diterima 27 November 2021, Direvisi 30 November 2021, Disetujui 30 November 2021

\begin{abstract}
ABSTRAK
Mengatasi tantangan yang ditimbulkan oleh penduduk pedesaan adalah topik yang sangat menarik bagi pemasar, pembuat kebijakan, dan peneliti. Namun, hanya ada sedikit penelitian tentang bagaimana penduduk pedesaan menerima atau menolak teknologi digital baru. Dengan perubahan kekuatan ekonomi dan tingkat adopsi ketika komunitas digital tumbuh antara daerah perkotaan dan pedesaan, menjadi semakin penting bagi pemasar untuk memahami bagaimana mereka menggunakan teknologi dan bagaimana mereka menggunakan saluran digital. Agar pemasar dan pembuat kebijakan memahami sepenuhnya bentuk masa depan masyarakat digital berbasis data, penelitian perlu lebih mempertimbangkan dampaknya terhadap kelompok generasi yang berbeda dalam hal adopsi dan penggunaan teknologi digital oleh konsumen di daerah pedesaan.Melalui tinjauan multidisiplin literatur tentang orang-orang tradisional menggunakan lensa teoritis kelompok geografis, penulis mengidentifikasi tantangan penelitian utama, peluang, dan dampak bagi pemasar dan pembuat kebijakan.
\end{abstract}

Kata Kunci : pemasaran digital; kebijakan publik; kesenjangan demografis; generasi; kesenjangan digital

\begin{abstract}
Addressing the challenges posed by rural populations is a topic of great interest to marketers, policymakers, and researchers. However, there is little research on how rural residents accept or reject new digital technologies. With changing economic power and adoption rates as digital communities grow between urban and rural areas, it is becoming increasingly important for marketers to understand how they use technology and digital channels. For marketers and policymakers to fully understand the future shape of a data-driven digital society, research needs to consider its impact on different generational groups in terms of consumer adoption and use of digital technology in rural areas. Through a multidisciplinary review of the literature on traditional people using a theoretical lens geographical group, the authors identify key research challenges, opportunities, and impacts for marketers and policymakers.
\end{abstract}

Keywords : digital marketing; public policy; demographic gap; generation; digital gap

\section{PENDAHULUAN}

Perubahan demografi dan populasi yang menua adalah tren makro yang memengaruhi sebagian besar aspek kehidupan sosial ekonomi abad kedua puluh satu. Permintaan konsumen berkembang seiring dengan perubahan kebutuhan, keinginan, dan nilai setiap generasi dilingkungan yang berbeda. Mereka yang didefinisikan sebagai "orang kampung", penduduk pedesaan, yang berbeda dari penduduk perkotaan dan pada gilirannya akan berbeda dari segi kebutuhan, keinginan masa depan. Meskipun penelitian tentang perspektif konsumen penduduk pedesaan diakui sebagai hal yang penting, ada kekurangan penelitian tentang cara berbagai kelompok konsumen "orang kampung"mengadopsi atau menolak teknologi digital. Hal ini diperkuat oleh perspektif yang tidak lengkap, kurang jelas, dan relatif tidak berubah pada konsumen "orang kampung" didorong oleh stereotip usang yang menempatkan "orang kampung" ke dalam satu kelompok. Namun, konsumen perkotaan berbeda dengan konsumen "orang kampung" yang lebih ditentukan oleh fasilitas publik. Kurangnya adopsi teknologi digital kemungkinan besar akan ditemukan di antara 
penduduk pedesaan (Camilleri, 2020). Namun semakin meningkat ketika konsumen "orang kampung muda-tua" secara aktif mengadopsi berbagai teknologi digital dan mewakili segmen pengguna media sosial yang berkembang, siklus generasi akan menentukan bahwa dengan setiap generasi " penduduk pedesaan muda-tua, penelitian lebih lanjut diperlukan untuk memahami implikasi kebijakan publik dan menginformasikan strategi pemasaran. Cukup dengan asumsi bahwa penduduk pedesaan di masa depan akan menanggapi aktivitas pemasaran dengan cara yang sama seperti penduduk perkotaan yang memungkinkan mendapatkan kondisi yang lebih buruk. (Camilleri, 2020).

Pentingnya komersial untuk memahami setiap kelompok penduduk pedesaan terletak pada kekuatan ekonomi mereka dan peluang teknologi digital untuk meningkatkan produk dan layanan. Selanjutnya, kegagalan untuk menangani segmen pasar ini menimbulkan implikasi kebijakan publik(Mogaji, Soetan, \& Kieu, 2021). Jika banyak konsumen penduduk pedesaan tidak dapat mengakses perangkat keras, perangkat lunak, atau infrastruktur yang diperlukan untuk mengonsumsi produk atau layanan tertentu, mereka berisiko dikecualikan secara digital. Karena peran platform digital dalam komunikasi, termasuk melalui media sosial atau aplikasi perpesanan, eksklusi digital menciptakan risiko eksklusi sosial.(Hair, Harrison, \& Risher, 2018)

Tujuan artikel ini adalah untuk mengembangkan agenda penelitian yang didasarkan pada teori yang menghubungkan literatur interdisipliner tentang kelompok penduduk pedesaan generasi muda-tua dengan tantangan dari teknologi digital. Kami pertama-tama menetapkan teori kohort generasi sebagai lensa kami untuk mengeksplorasi generasi berdasarkan letak geografis. Kami kemudian memeriksa perspektif penelitian yang berbeda tentang penduduk pedesaan generasi muda-tua yang kami selaraskan dengan area inti dalam pemasaran digital untuk mengidentifikasi sejauh mana kesenjangan digital. Akhirnya, kami membahas agenda penelitian, tantangan pemasaran digital, dan implikasi kebijakan publik.

Perubahan dalam struktur populasi penting karena sejauh mana kehidupan organisasi dan sosial sering dibangun di atas pengertian usia masa lalu daripada perubahan masa kini dan masa depan. Dengan demikian, kehidupan di negara-negara industri biasanya terstruktur seputar transisi terkait usia dari pendidikan ke pekerjaan hingga pensiun
(Sharma, Sharma, \& Chaudhary, 2020). Asumsi ekonomi yang tertanam adalah bahwa ada cukup banyak pekerjaan untuk mendukung mereka yang tidak bekerja. Peningkatan pendapatan, kesehatan, dan nutrisi baru-baru ini telah menghasilkan peningkatan umur panjang, dan populasi yang menua meningkatkan tantangan pemasaran dan kebijakan publik (Sharma et al., 2020). Demikian pula, praktik kerja yang fleksibel dan transisi bertahap antara tahap kehidupan menghasilkan lebih banyak heterogenitas di antara individu yang lebih pada generasi tua, yang memerlukan pemeriksaan ulang terhadap pandangan yang ada. Dalam pemasaran, letak geografis dan usia sering dikonseptualisasikan dalam istilah kronologis, di mana rentang produk ditargetkan untuk mereka yang berusia di atas usia tertentu (misalnya 65 tahun). Namun dalam rentang usia yang luas ini, perlu untuk memperhitungkan perbedaan kelompok dengan mengelompokkan konsumen ke dalam mereka yang memasuki sistem pada waktu yang hampir bersamaan, seringkali dengan pengalaman masa lalu yang sama. Sebuah kelompok mungkin telah dipengaruhi oleh peristiwa politik, sosial, dan lainnya, yang telah mempengaruhi nilai-nilai mereka. Kelompok generasi berbeda di seluruh konteks nasional karena berbagai peristiwa sosial, politik, dan ekonomi berbasis kontekstual yang mereka alami. Dengan demikian, perbedaan usia dapat dirasakan melalui lensa teoretis dari kelompok generasi. Namun lensa ini juga multifokal dalam kaitannya dengan perspektif penelitian yang muncul dari literatur multidisiplin, yang kami gunakan untuk menginformasikan topik penelitian ini.

\section{Perspektif Kelompok Generasi dan Wilayah Geografis}

Generasi tua-muda, dan wilayah adalah konstruksi multilevel, multidimensi, dan pengambilan keputusan dan perilaku konsumen dapat dijelaskan melalui perspektif disiplin yang berbeda (Dwityas, Mulyana, Hesti, Briandana, \& Kurniasari, 2020). Perspektif ini mencerminkan dimensi biologis/fisik, psikologis/kognitif, dan sosial dari perbedaan generasi dan wilayah geografis (Muniraju \& Bhojaraja, 2018). Konteks lingkungan di mana gap terjadi harus dieksplorasi juga. Kami menambahkan nilai pada perspektif ini dengan mengabstraksi dari tema literatur yang berkaitan dengan cara konsumen penduduk pedesaan mengadopsi/menolak teknologi digital. Kami juga mengidentifikasi apa yang tidak termasuk dalam literatur dalam hal kesenjangan penting, masalah yang membutuhkan perhatian, dan yang memiliki 
implikasi kebijakan. Ini mengarah pada identifikasi implikasi pemasaran dan kebijakan publik dari tantangan teknologi digital ini untuk kelompok "orang kampung muda-tua".

a). Perspektif Kelompok Generasi muda-tua Perspektif ini menganggap faktor generasi muda-tua sebagai fungsi biologis yang secara khusus terkait dengan perubahan tubuh dari waktu ke waktu yang memengaruhi kesehatan dan fungsi fisik (K. H. Kim \& Moon, 2021). Perspektif ini biasanya digunakan untuk menjelaskan perbedaan bagaimana generasi secara fisik, seperti penurunan sensorik dalam penglihatan dan pendengaran (Katsikeas, Leonidou, \& Zeriti, 2020). Ini membentuk dasar desain produk atau layanan untuk konsumen yang berada generasi muda-tua berbeda, menggabungkan asumsi sekitar, misalnya, mobilitas atau visi yang buruk. Gap generasi sering digunakan sebagai proksi untuk generasi muda-tua, meskipun ada hubungan yang lemah mengingat sejauh mana yang terakhir bervariasi(Steinhoff \& Palmatier, 2021). Efek gap generasi muda-tua berbeda dengan efek dari konteks lingkungan dan faktor pengalaman lainnya.

b). Perspektif Kelompok Sosial Wilayah Geografis

Konteks wilayah geografis, dan implikasinya terhadap hubungan individu, memainkan peran penting dalam memahami perilaku kelompok ini. Kelompok sosial wilayah geografis terbentuk dalam konteks nasional yang berbeda berdasarkan peristiwa budaya dan politik yang dialami. Juga generasi global yang lebih luas terbentuk karena peristiwa yang dialami secara global. Perspektif kelompok sosial wilayah geografis sosial termasuk bagaimana individu berhubungan satu sama lain di seluruh generasi, mencerminkan pertanyaan yang berkembang tentang kesetaraan antar generasi dan menghasilkan perdebatan kebijakan publik, seperti pada kebijakan kesehatan dan tanggung jawab untuk generasi mendatang(Susilo, 2018).

c). Perspektif Lingkungan Geografis

Para sarjana di bidang-bidang seperti geografi dan ilmu sosial telah lama mengakui hubungan antara gap generasi dan lingkungan fisik dan cara-cara di mana perubahan lingkungan dapat meningkatkan pengalaman generasi. Dalam masyarakat dengan peningkatan terbesar dalam proporsi generasi tua, seperti Jepang dan Italia, telah terjadi migrasi anggota masyarakat yang lebih muda ke kota, dengan orang tua yang tertinggal di daerah pedesaan. Pertanyaan tentang lokasi fisik sangat relevan sejauh sifat virtual saluran digital dapat memungkinkan konsumen yang lebih tua untuk mengatasi keterbatasan lingkungan fisik. Untuk kelompok generasi yang lebih tua, diakui bahwa "dampak (sering membingungkan) lingkungan pada nilai, perilaku dan sikap" juga harus diperhitungkan sebagai "efek periode" jika berusaha mengidentifikasi generasi, kelompok atau usia -dampak terkait. Mengacu pada efek periode kritis ketika preferensi untuk produk dan selera lainnya ditetapkan, biasanya terjadi pada masa remaja akhir atau pada awal masa dewasa(Mary C. Lacity \& P.Willcocks, 2016).

\section{Tradisional Marketing VS Digital Marketing}

Pemasaran tradisional adalah bentuk pemasaran yang paling dikenal. Pemasaran tradisional adalah cara non-digital yang digunakan untuk mempromosikan produk atau layanan badan usaha. Di sisi lain, pemasaran digital adalah pemasaran produk atau layanan menggunakan saluran digital untuk menjangkau konsumen. Beberapa perbandingan disajikan di Tabel 1.

Tabel 1: Perbandingan pemasaran tradisional dan pemasaran digital Tradisional Marketing

Pemasaran tradisional meliputi media cetak, siaran, surat langsung, dan telepon

\section{Digital Marketing}

Pemasaran digital mencakup periklanan online, pemasaran email, media sosial, pesan teks, pemasaran afiliasi, optimisasi mesin pencari, bayar per klik

\begin{tabular}{ll}
\hline Tidak ada interaksi dengan penonton & Interaksi dengan penonton \\
\hline Hasil mudah diukur & Hasil sebagian besar mudah diukur \\
\hline $\begin{array}{l}\text { Kampanye iklan direncanakan dalam jangka } \\
\text { waktu yang lama }\end{array}$ & $\begin{array}{l}\text { Kampanye iklan direncanakan dalam waktu } \\
\text { singkat }\end{array}$ \\
\hline Proses mahal dan memakan waktu & $\begin{array}{l}\text { Cara yang cukup murah dan cepat untuk } \\
\text { mempromosikan produk atau layanan }\end{array}$ \\
\hline $\begin{array}{l}\text { Keberhasilan strategi pemasaran tradisional } \\
\text { dapat dirayakan jika perusahaan dapat } \\
\text { menjangkau khalayak lokal yang besar }\end{array}$ & $\begin{array}{l}\text { Keberhasilan strategi pemasaran digital dapat } \\
\text { dirayakan jika perusahaan dapat menjangkau } \\
\text { sejumlah audiens lokal tertentu }\end{array}$ \\
\hline Satu kampanye berlaku untuk waktu yang lama & $\begin{array}{l}\text { Kampanye dapat dengan mudah diubah dengan } \\
\text { mudah dan inovasi dapat diperkenalkan dalam } \\
\text { kampanye apa pun }\end{array}$ \\
\hline
\end{tabular}




\begin{tabular}{|c|c|}
\hline $\begin{array}{l}\text { Jangkauan terbatas ke pelanggan karena jumlah } \\
\text { teknologi pelanggan }\end{array}$ & $\begin{array}{l}\text { Jangkauan lebih luas ke pelanggan karena } \\
\text { penggunaan berbagai teknologi pelanggan }\end{array}$ \\
\hline $\begin{array}{l}\text { Paparan } 24 / 7 \text { sepanjang tahun tidak mungkin } \\
\text { Tidak ada kemampuan untuk menjadi viral } \\
\text { Percakapan satu arah }\end{array}$ & Eksposur 24/7 sepanjang tahun dimungkinkan \\
\hline Tidak ada kemampuan untuk menjadi viral & Kemampuan untuk menjadi viral \\
\hline Percakapan satu arah & Percakapan dua arah \\
\hline Tanggapan hanya dapat terjadi selama jam kerja & $\begin{array}{l}\text { Tanggapan atau umpan balik dapat terjadi kapan } \\
\text { saja }\end{array}$ \\
\hline
\end{tabular}

Media periklanan yang dapat digunakan sebagai bagian dari strategi pemasaran digital suatu bisnis dapat mencakup upaya promosi yang dilakukan melalui internet, media sosial, telepon seluler, papan reklame elektronik, serta melalui saluran televisi dan radio digital. Pemasaran digital adalah sub cabang dari pemasaran tradisional dan menggunakan saluran digital modern untuk penempatan produk misalnya musik yang dapat diunduh, terutama untuk berkomunikasi dengan pemangku kepentingan, contohnya. pelanggan dan investor tentang merek, produk, dan kemajuan bisnis.

\section{Kesenjangan Digital dan Kesenjangan Demografis dalam Pemasaran}

Masalah "penolakan demografis" dalam pemasaran dengan mengabaikan orang tua dan fokus pada pasar anak muda, terlepas dari pergeseran kekuatan ekonomi, telah banyak dibahas (Kannan \& Li, 2017), ulasan penelitian tentang gap genereasi dalam konteks pemasaran (Marescotti et al., 2020) merangkum tantangan, menyoroti kurangnya penelitian pemasaran tentang gap generasi muda-tua dan kurangnya lensa teoretis untuk mempelajari fenomena terkait. Kelemahan penelitian yang ada adalah fokus semata-mata pada bagaimana faktor yang berkaitan dengan usia, seperti perubahan fisik, psikologis, atau lingkungan sosial, mempengaruhi perilaku. Dengan mengabaikan faktor kontekstual dan temporal yang mempengaruhi keputusan pembelian, studi penelitian tidak cukup mengembangkan atau analisis yang tidak bernuansa tentang cara konsumen yang lebih tua berperilaku(Royle \& Laing, 2014).

Perubahan perilaku terkait usia mencerminkan cara yang kompleks dan halus bahwa gap generasi, gap demografis memengaruhi pengambilan keputusan konsumen. Misalnya, hal ini dapat diamati dengan riset pasar menggunakan telepon, ketika responden yang lebih tua cenderung memilih jawaban yang paling baru (Wijaya. $\mathrm{Ni}$ Putu, 2021). Pandangan negatif peneliti muda tentang gap generasi juga dapat mempengaruhi pendekatan mereka untuk mengajukan pertanyaan dan menghasilkan penilaian kognitif negatif atau harga diri yang lebih rendah di benak responden yang lebih tua(Royle \& Laing, 2014). Sebaliknya, penelitian yang berfokus pada nostalgia dapat melibatkan dan mengatasi pengaruh pengalaman masa lalu pada preferensi merek kelompok yang lebih tua "terhadap objek (orang, tempat, atau benda) yang lebih umum (populer, modis, atau beredar luas) ketika seseorang masih muda. Nostalgia mencerminkan bagaimana preferensi usia dewasa dapat memengaruhi nilai(Leeflang, Verhoef, Dahlström, \& Freundt, 2014) dan pola konsumsi di kemudian hari. Batas usia untuk pengalaman formatif yang mempengaruhi nostalgia tergantung pada kategori produk, tetapi umumnya dianggap selama 20 -an orang, konsumen yang lebih muda lebih cenderung memilih merek baru, mereka lebih sering berganti merek dan dengan demikian merupakan prospek yang lebih singkat daripada konsumen yang lebih tua yang tetap bertahan. merek lebih lama tetapi masih mau mencoba produk baru. Hal ini menunjukkan bahwa konsumen yang lebih tua dapat menjadi lebih berharga karena kesediaan mereka untuk beralih merek ketika disajikan dengan penawaran yang lebih menarik sambil tetap bertahan dengan merek yang membuat mereka puas. Namun, terlepas dari penelitian ini, penelitian tentang gap generasi muda-tua dan pemasaran masih relatif terbatas dalam ruang lingkup. Satu penjelasan untuk ini adalah bahwa penuaan membawa simbolisme yang mengisolasinya dari agenda penelitian yang semakin terfokus pada saluran digital, yang dicirikan terutama sebagai fenomena kelompok usia muda. Ini tertanam dalam stereotip konsumen yang lebih tua dan kelompok generasi yang menunjukkan bahwa mereka memiliki sedikit kesamaan dengan pola penggunaan dunia nyata saat ini atau masa depan.

Mengingat generalisasi konsep penuaan, tidak mengherankan bahwa banyak penelitian tentang penuaan di bidang lain telah menyentuh konsumsi barang dan jasa. Namun ini disertai dengan keterbatasan dalam hal aplikasi untuk pemasaran digital. Pertama, karena penelitian tentang penuaan seperti itu 
biasanya dibingkai oleh masalah kesehatan, ada fokus pada mereka yang memiliki kebutuhan kesehatan terbesar, menciptakan pergeseran ke kohort tertua, seperti ketika mengeksplorasi hambatan persepsi untuk adopsi bagi mereka yang tidak menggunakan internet. untuk media sosial, terlibat dengan layanan publik, atau melakukan pembelian (Rose, Hair, \& Clark, 2011). Meskipun penting untuk memahami mengapa "tua-tua" tidak menggunakan layanan online, itu berisiko mengaburkan pemahaman kebutuhan mereka yang melakukannya, seperti kelompok "mudatua". Dari perspektif pemasaran, fokus pada konsumsi melalui lensa kebutuhan kesehatan memiliki efek potensial memperkuat asumsi dan stereotip yang ada tentang kemampuan individu yang lebih tua sambil mengabaikan kebutuhan mereka sebagai konsumen. Aliran penelitian dalam literatur manajemen berfokus pada pola adopsi teknologi, di mana usia sering digunakan sebagai variabel. Jadi, dalam teori penerimaan dan penggunaan teknologiterpadu, mungkin yang paling sering ditampilkan dari model ini, usia disajikan sebagai moderator niat perilaku dan perilaku pengguna. Meskipun sejumlah besar penelitian menyelidiki teori ini, hanya sedikit yang didasarkan pada teknologi konsumen (Muniraju \& Bhojaraja, 2018)dan sedikit yang mengidentifikasi hubungan yang signifikan antara usia dan adopsi teknologi. Selain itu, meskipun usia merupakan variabel, ini tidak berarti penelitian berfokus pada konsumen penduduk pedesaan yang menua atau lebih tua. Beberapa studi yang berfokus pada usia mempertimbangkan perbedaan antara anak-anak dan orang dewasa (Zhang, 2010) atau sampel konsumen dengan usia ratarata yang relatif muda dan sedikit konsumen yang lebih tua yang diwakili.

\section{METODE}

Metodologi berasal dari analisis sistematis dan teoritis metode untuk mengevaluasi kesesuaian satu metode tertentu untuk diterapkan pada bidang studi. Ini biasanya mencakup konsepkonsep seperti paradigma, model teoritis, fase dan teknik kuantitatif atau kualitatif. Penelitian ini dilakukan berdasarkan sumber data primer dan sekunder.

Sumber utama:

Sumber primer adalah sumber dari mana kami mengumpulkan informasi tangan pertama atau data asli tentang penjualan songkok racca. Teknik wawancara digunakan dengan kuesioner terstruktur untuk pengumpulan data primer.

Sumber kedua:

Sumber sekunder adalah sumber dari mana kami mengumpulkan data yang telah dikumpulkan. Kami telah mengumpulkan data sekunder dari laporan keuangan yang diterbitkan perusahaan, surat kabar dan artikel. Untuk tujuan penelitian ini, kami telah memilih seratus lima puluh Usaha Mikro, Kecil dan Menengah (UMKM) secara acak yang menggunakan sistem pemasaran digital untuk menjual produk mereka kepada pelanggan. Selain itu, kami juga mengumpulkan data dari 50 eksekutif dari sampel dan UMKM lain yang berbeda untuk mengetahui pendapat mereka tentang efektivitas pemasaran digital. Data dan informasi yang dikumpulkan telah diatur, dijelaskan, dan dianalisis dengan menggunakan alat dan teknik reduksi data. Studi ini menunjukkan hasil baik secara deskriptif maupun analitis.

Metode Pendekatan yang ditawarkan untuk mendukung realisasi program adalah Metode Adactive Collaboration Management (ACM) dilakukan dengan pendekatan komunikasi masyarakat dalam menemu kenali permasalahan masyarakat, mempelajari permasalahan kemudian menentukan solusi pemecahan masyarakat. Selain itu metode pendekatan yang akan digunakan dalam program pengabdian ini adalah pendidikan dan pelatihan yang partisipatif atau educational and participatory approach. Metode ini memposisikan khalayak sasaran sebagai penerima pengetahuan, pemahaman dan ketrampilan tentang cara produksi, innovasi dan pemasaran songkok recca agar bernilai ekonomi yang tinggi. Dimana kelompok pengrajin dilibatkan dalam seluruh kegiatan mulai dari perencanaan, pelaksanaan, monitoring dan evaluasi. Selain itu dilakukan penyuluhan partisipatif yaitu dengan melakukan kegiatan pembelajaran tentang Usaha Mikro, Kecil dan Menengah yang Tangguh, Mandiri dan mempunyai tingkat daya saing yang tinggi Dalam kegiatan program ini direncanakan untuk melibatkan 150 UMKM pengrajin sebagai peserta dari beberapa kelompok dan ibu-ibu PKK yang ada di kabupaten bone. Selanjutnya dari seluruh peserta dibagi dalam beberapa kelompok, sehingga masing-masing kelompok yang telah dilatih diharapkan dapat menyebarluaskan kepada anggota kelompok lainnya. Untuk menilai tingkat keberhasilan dari pelaksanaan kegiatan pengabdian khalayak sasaran akan dilakukan evaluasi yang meliputi empat kriteria yang telah ditetapkan yaitu : kehadiran, perencanaan kegiatan, penyuluhan dan pelatihan.

\section{Hasil dan Pembahasan \\ I. Adopsi Teknologi Digital}

Kami menyelaraskan perspektif penelitian dengan tujuh bidang inti di mana kami 
mengidentifikasi adopsi konsumen penduduk pedesaan atau penggunaan teknologi digital dan dampaknya terhadap pemasaran dan kebijakan publik, menawarkan agenda penelitian untuk setiap area yang teridentifikasi. Peluang untuk penciptaan nilai disorot oleh analisis informasi teoritis kami tentang kebutuhan konsumen penduduk pedesaan, yang dikategorikan berdasarkan tujuh bidang ini. Ini semakin penting untuk penelitian, karena stereotip khusus usia mencirikan diskusi tentang konsumen penduduk pedesaan dan teknologi digital. Perbedaan generasi dalam penggunaan dan adopsi teknologi tertentu dapat dikaitkan dengan waktu dan riwayat daripada perbedaan apa pun yang tertanam dalam proses. Pertama, media sosial dan periklanan digital adalah dua konteks teknologi yang umum dalam literatur pemasaran kontemporer. Adopsi konsumen media sosial menyediakan platform tidak hanya untuk membina hubungan pelanggan(De Vries, Gensler, \& Leeflang, 2012), tetapi bagi pelanggan untuk mempengaruhi perilaku pembelian dengan berbagi pengalaman online produk dan layanan (Royle \& Laing, 2014). Pergeseran ke iklan online membawa masalah atas keterlibatan dan penurunan keuntungan finansial(Diez-Martin, Blanco-Gonzalez, \& Prado-Roman, 2019). Mengingat ketergantungan ekonomi digital pada periklanan, memahami cara melibatkan semua kelompok adalah area penelitian utama. Tiga aspek teknologi juga harus disorot dalam ritel dan pengiriman layanan. Meningkatnya peran teknologi otomasi layanan (misalnya, mesin swalayan, aplikasi), di mana teknologi menggantikan staf yang menghadap pelanggan, menimbulkan pertanyaan tentang bagaimana otomasi memengaruhi persepsi kualitas layanan di berbagai kelompok konsumen. Secara terpisah, pergeseran ke ritel online memiliki dampak mendasar pada berbagai produk yang tersedia bagi konsumen, sambil mempertanyakan kelangsungan hidup sebagian besar lingkungan ritel yang ada. Selain itu, penyampaian pengalaman pelanggan online yang efektif sekarang menjadi keharusan strategis utama bagi pemasar(Leeflang et al., 2014). Ini termasuk cara agar layanan online dapat mereplikasi aspek eksperimental dari penawaran layanan offline dan aspek yang lebih teknis dari pengalaman pengguna dari desain layanan web atau aplikasi itu sendiri.

\section{Media Sosial}

Meskipun penggunaan media sosial telah banyak diasosiasikan dengan kelompok konsumen yang lebih muda, seiring dengan perkembangan teknologi, penggunaannya semakin meningkat di mana-mana di antara pengguna internet, sebagaimana dibuktikan oleh 2,85 miliar. Sebanyak 81,8 persen pengguna Facebook (Facebook 2021). Data terbatas yang tersedia menunjukkan bahwa platform yang ada memberikan utilitas yang signifikan bagi konsumen yang lebih tua yang juga pengguna internet. Misalnya, pada akhir tahun 2020, 62\% orang dewasa Indonesia online berusia di atas 65 tahun menggunakan Facebook dibandingkan dengan $72 \%$ pada kelompok usia 30-49 tahun. Apa yang penting dari data ini adalah tingkat adopsi meningkat untuk kelompok di atas 65 , yang tumbuh dari $48 \%$ menjadi $62 \%$ dalam satu tahun. Media sosial dapat dicirikan sebagai memainkan peran yang semakin penting dalam bagaimana pengguna internet yang lebih tua berkomunikasi secara online.

Dengan mengaktifkan hubungan online, media sosial menyediakan cara untuk mengatasi hambatan tersebut, bahkan menggantikan interaksi fisik dengan virtual. Bagi peneliti, ini menimbulkan dua pertanyaan: Apa pendorong dan hambatan adopsi media sosial oleh kelompok penduduk perkotaan dan penduduk pedesaan ? Dengan cara apa faktor terkait kesenjangan Demografis memengaruhi pola interaksi dan penggunaan dalam platform ini? Dari perspektif pemasaran, pertanyaan tentang penggunaan berkaitan dengan bagaimana konten buatan pengguna dibuat atau digunakan.

Satu perbedaan terkait kesenjangan demografis berkaitan dengan jumlah koneksi di setiap jaringan, dengan pengguna yang penduduk perkotaan memiliki jumlah "teman" yang jauh lebih besar di Facebook(Kezer, Sevi, Cemalcilar, \& Baruh, 2016). Namun, hal ini tidak serta merta mengarah pada hubungan sosial yang lebih kuat. Meskipun media sosial telah diidentifikasi sebagai sumber modal penghubung, telah terbukti relatif lemah sebagai sumber modal ikatan, bentuk modal sosial yang paling dihargai oleh kelompok penduduk pedesaan (Al-Afifi, Yasmin, Tasneem, \& Fatema, 2015). Demikian pula, dorongan oleh teman dan kerabat yang merupakan pengguna media sosial merupakan faktor penting dalam adopsi (Royle \& Laing, 2014). Faktor lain yang mempengaruhi jumlah informasi yang bersedia diungkapkan oleh pengguna penduduk pedesaan di media sosial termasuk kekhawatiran atas privasi (Quinn, 2021), kemampuan untuk mengikuti dan menanggapi norma-norma sosial, dan kemampuan untuk mempertahankan kendali atas konteks online di lingkungan di mana 
anonimitas dapat menimbulkan keraguan atas niat orang lain.

Faktor-faktor ini menunjukkan bahwa ada aspek terkait usia dalam penggunaan media sosial yang memerlukan penelitian lebih lanjut. Bahkan jika pengguna yang penduduk pedesaan memiliki jaringan sosial yang lebih kecil, kesediaan mereka untuk memasukkan pendapat orang lain ke dalam proses pengambilan keputusan mereka membuatnya lebih penting untuk memahami dampak media sosial. Memang, tingkat ekspresi diri yang lebih rendah yang terkait dengan penggunaan media sosial oleh kelompok yang lebih tua dapat mengarah pada peran yang berpotensi lebih besar untuk UMKM kolaboratif yang pada gilirannya dapat menghasilkan berita positif dari mulut ke mulut (Leeflang et al., 2014). Pentingnya dan keberadaan media sosial membuat pengisian kesenjangan penelitian ini menjadi semakin kritis.

\section{Periklanan Digital}

Periklanan telah diidentifikasi memiliki dampak besar pada bagaimana masyarakat memandang individu penduduk pedesaan, terutama karena ketidakhadiran mereka dan stereotip negatif dalam periklanan. Selain mempertimbangkan perbedaan tanggapan demografi terhadap iklan(Mary C. Lacity \& P.Willcocks, 2016) kelompok yang penduduk pedesaan berpikir bahwa mereka digambarkan secara negative. Ini tidak mengejutkan mengingat cara periklanan menyebarkan "pasar metropolitan" dan mengecualikan atau membuat karikatur individu penduduk pedesaan dalam citra iklan. Namun, faktor yang lebih teknis adalah kualitas.

Data yang dikumpulkan di media sosial, mesin pencari, dan aktivitas online lainnya menciptakan peluang bagi pemasar untuk menggunakan gap generaso yang akurat sebagai variabel. Jadi, meskipun pengguna tidak masuk log, Google dapat "menyimpulkan informasi demografis mereka berdasarkan aktivitas mereka dari properti Google atau Jaringan Display". Hal ini menunjukkan bahwa meningkatkan akurasi usia kronologis dapat menjadikannya variabel yang lebih efektif untuk digunakan dalam periklanan untuk menargetkan kelompok generasi yang lebih tua di masa mendatang.

\section{Otomatisasi Layanan}

Penggerak utama pemasaran jasa adalah standarisasi pemberian layanan agar lebih efisien dan konsisten (Mary C. Lacity \& P.Willcocks, 2016). Seiring kemajuan teknologi dan pengurangan biaya, otomatisasi peran layanan dipandang sebagai rute menuju efisiensi dan konsistensi. Meskipun tujuan otomatisasi biasanya untuk menghemat tenaga kerja (Tristanto, n.d.) penghapusan staf yang menghadapi pelanggan berisiko menurunkan kualitas layanan dengan menghilangkan fungsi sosial yang tertanam dalam pertemuan layanan. Penelitian telah lama menunjukkan bahwa pengurangan layanan pribadi melalui pengenalan teknologi swalayan mengurangi kepuasan dan komitmen pelanggan, meskipun efek ini dapat dikurangi melalui penggunaan teknologi swalayan yang menarik dan interaktif (Sands, Harper, \& Ferraro, 2011).

Otomatisasi layanan dapat membawa keuntungan dan kerugian bagi konsumen penduduk pedesaan. Sistem layanan otomatis dapat memberikan tingkat layanan yang disesuaikan dan bahkan kesabaran yang lebih tinggi. Layanan otomatis dapat direkayasa untuk fleksibilitas, dan penelitian telah menunjukkan bahwa pelanggan lebih cenderung meninggalkan instruksi terperinci dan memesan item dengan nama yang sulit diucapkan saat menggunakan layanan otomatis (Goldfarb, McDevitt, Samila, \& Silverman, 2015). Konsumen penduduk pedesaan ingin menghindari penilaian sosial yang negatif (Goldfarb et al., 2015), sehingga mereka mendapat manfaat dari keakuratan interaksi layanan otomatis tanpa dinilai karena kesalahan atau keterbatasan teknologi mereka. Namun penelitian juga menunjukkan bahwa interaksi tatap muka merupakan bagian penting dari layanan bagi konsumen pedesaan, yang cenderung mengandalkan individu lain dalam pengambilan keputusan mereka di berbagai bidang.

\section{Ritel Online}

Sementara data media sosial bersifat ambigu dalam kaitannya dengan konsumen pedesaan bukti menunjukkan bahwa konsumen ini bersedia mengadopsi ritel online seperti halnya konsumen yang lebih muda(Doshi, 2018). Ritel online memberikan keuntungan praktis yang memungkinkan orang untuk membeli barang tanpa dibatasi oleh batas demografis Selain itu, pembelian online memungkinkan individu untuk mengurangi kelebihan kognitif dan meningkatkan pengambilan keputusan dengan dapat dengan mudah memilih dari pesanan sebelumnya atau preferensi yang sudah ada sebelumnya. Sementara faktor-faktor ini berfokus pada aspek negatif gap generasi, motivasi ekonomi adalah bahwa kelompok yang lebih tua lebih cenderung menggunakan belanja online jika dan ketika mereka memiliki kekuatan ekonomi yang lebih besar dan pendapatan yang dapat dibelanjakan lebih tinggi. Namun, pembelian 
online datang dengan tantangan dan risikonya sendiri, termasuk kurangnya kurasi, adanya terlalu banyak pilihan, dan kesulitan mengidentifikasi produk dengan kualitas rendah atau di bawah standar. Hal ini penting karena konsumen pedesaan cenderung terlibat dalam tingkat pencarian informasi yang lebih rendah dan menunjukkan kemungkinan yang lebih rendah untuk beralih merek. Jika saluran digital memungkinkan pencarian informasi yang lebih mudah, terutama dalam hal mengidentifikasi barang dan jasa berkualitas lebih tinggi atau lebih rendah, maka tingkat peralihan merek yang lebih tinggi dapat didorong.

\section{Pengalaman Pelanggan Online}

Menciptakan pengalaman pelanggan yang unggul adalah prinsip utama dari strategi pemasaran yang efektif. Namun pengalaman pelanggan yang efektif seringkali didasarkan pada hubungan pribadi dengan anggota staf atau lingkungan fisik toko. Hal ini menciptakan tantangan bagi layanan yang disampaikan secara online, karena keuntungan dalam efisiensi atau kemudahan penggunaan harus dipertimbangkan terhadap potensi kerugian dalam kualitas pengalaman melalui "kesetiaan" yang lebih rendah. Unsur-unsur manusia yang mempengaruhi pengambilan keputusan afektif dan kognitif dalam pengalaman offline digantikan oleh faktor-faktor yang berhubungan dengan pengalaman antarmuka teknis dengan platform digital (Rose et al., 2011).

Sementara banyak penelitian tentang pengalaman pelanggan didasarkan pada penggunaan situs web berbasis komputer, jangkauan dan sifat titik kontak dengan teknologi berubah, seperti pertumbuhan perangkat seluler dan perluasan jenis media. Selain itu, meskipun ada banyak penelitian tentang media berbasis teks, komunikasi pada saluran digital semakin ditandai oleh video, foto, audio, dan bentuk media hibrida seperti emotikon.

\section{Implikasi bagi Kebijakan Publik}

Teknologi digital baru memberikan manfaat yang signifikan bagi peningkatan jumlah anggota masyarakat yang lebih tua (K.I. Kim, Gollamudi, \& Steinhubl, 2017). Mereka dapat mengurangi tingkat isolasi yang terkait dengan usia tua dengan memungkinkan konektivitas dengan teman dan anggota keluarga (Olphert \& Damodaran, 2013) Layanan e-commerce menyediakan pengiriman barang yang cepat kepada mereka yang memiliki masalah mobilitas. Secara lebih luas, penyedia layanan publik telah mulai membangun layanan mereka sendiri di platform digital, termasuk jejaring sosial, untuk menyebarkan informasi dan saran. Mengingat manfaat ekonomi dari melayani konsumen yang lebih tua, dapat dikatakan bahwa pasar pada akhirnya akan mengatasi kesenjangan apa pun dan bahwa kesenjangan digital saat ini adalah fungsi dari tingkat adopsi teknologi yang berbeda. Namun demikian, pembuatan kebijakan tetap penting untuk mempersempit kesenjangan digital (misalnya, dengan memfasilitasi penyediaan broadband yang mudah diakses) tidak hanya untuk penduduk pedesaan tetapi juga untuk populasi berpenghasilan rendah, dua kategori yang sering terkait untuk banyak rumah tangga.

Pertanyaan bagi pembuat kebijakan menyangkut langkah-langkah yang dapat diambil untuk memastikan bahwa konsumen penduduk pedesaan yang lebih tua tidak dikecualikan dari saluran digital dan akses itu tetap dipertahankan. Tantangannya adalah bahwa bentuk-bentuk pengecualian yang dibahas di sini biasanya bersifat implisit daripada eksplisit (Royle \& Laing, 2014). Platform digital disampaikan oleh perusahaan komersial yang beroperasi di pasar yang sangat kompetitif, di mana kelompok yang lebih tua tidak secara khusus dikecualikan dari mengadopsi platform ini. Meskipun ada masalah yang terkait dengan aksesibilitas fisik layanan, undang-undang yang tersebar luas sudah ada yang terkait dengan penggunaan platform web oleh pengguna yang terganggu.

Lebih sulit untuk mengatasi adalah bentuk pengecualian implisit yang terjadi pada platform di mana efek jaringan mendominasi. Meskipun fokus hubungan interpersonal orang muda di jejaring sosial dipahami dengan baik, pola ini dapat direplikasi dalam ekonomi berbagi. Misalnya, di mana keberadaan layanan seperti Tokopedia, Shopie, Lazada mengakibatkan toko-toko retail yang besar tutup, apakah cakupan jangkauan didorong oleh kebutuhan pengadopsi awal yang lebih muda yang mendominasi jaringan? Jika pemberian layanan berbiaya rendah atau cepat dari layanan ini hanya tersedia di lokasi perkotaan di mana populasinya cenderung lebih muda, apakah ada risiko implisit lain dengan mengecualikan konsumen dipedesaan?

Kami menyarankan bahwa rekomendasi kebijakan menyeluruh berdasarkan gap generasi, perbedaan demografis tidak mungkin efektif, karena berbagai cara dapat memengaruhi keputusan dan kebutuhan konsumsi. Banyak tantangan yang diidentifikasi, seperti yang berkaitan dengan disabilitas, mungkin berkorelasi dengan usia, tetapi mereka juga dapat mempengaruhi 
segmen populasi lainnya. Dengan demikian, beberapa organisasi, terutama Masyarakat Internet, memiliki agenda eksplisit yang tidak secara khusus didorong oleh usia. Ini bertujuan untuk mempengaruhi kebijakan publik melalui tujuan yang dinyatakan dari akses internet generik dan berkelanjutan, yang dipandang berada di bawah ancaman oleh "berbagai masalah sosial, ekonomi, peraturan dan kebijakan yang mengganggu Internet yang terbuka dan berkelanjutan" ("Policy Brief: Human Rights - Internet Society," n.d.)

Meskipun proporsi individu yang berada di sisi yang salah dari kesenjangan digital menurun dari waktu ke waktu, namun tetap merupakan kelompok besar, yang terdiri dari banyak anggota masyarakat yang paling rentan (Royle \& Laing, 2014) Pembuat kebijakan harus mempertimbangkan keadaan di mana opsi nondigital harus dipertahankan ketika layanan didigitalkan, seperti manfaat ganda dari memesan makanan dan bahan makanan secara online dikombinasikan dengan layanan pengiriman yang lebih personal. Dalam artikel ini, kami juga telah mengidentifikasi variasi terkait usia generasi dalam penggunaan platform digital. Mereka yang menyediakan layanan publik harus memperhatikan batasan jangkauan dengan beroperasi pada satu atau lebih platform tertentu. Penggunaan mobile banking berbasis aplikasi, misalnya, tertinggal dari adopsi dan penggunaan jejaring sosial. Pembuat kebijakan harus mempertimbangkan platform perangkat lunak dan perangkat keras mana yang diperlukan untuk penyampaian layanan penting.

\section{SIMPULAN}

Artikel ini mengidentifikasi implikasi dari populasi penduduk pedesaan dalam lingkungan pemasaran yang semakin didorong oleh teknologi, bergerak melampaui fokus sempit biaya kesehatan dan ekonomi. Dengan demikian, kami bertujuan untuk mengalihkan diskusi dari masalah demografis ke peluang untuk menggunakan teknologi digital yang menciptakan nilai bagi pelanggan pedesaan. Meskipun populasi penduduk pedesaan menciptakan implikasi yang luas untuk struktur pasar dan kebutuhan pelanggan, ada kekurangan studi empiris tentang hal ini dalam konteks pemasaran digital. Jadi, ketika mempertimbangkan hubungan antara gap generasi, penduduk desa dan teknologi baru, "suara" pemasaran sering tidak ada dalam literatur. Ketersediaan data yang terbatas terkait dengan usia dan pola penggunaan layanan digital saat ini. Bahkan dalam pelaporan data publik, profil usia pengguna jasa jarang dianggap sebagai variabel penting.
Misalnya, dalam pengajuan publik, Facebook memberikan perincian penggunanya dalam hal jenis kelamin, etnis, dan geografi, tetapi tanpa pengakuan profil usia (Facebook 2021). Agar pemasaran dapat berfokus secara efektif pada peningkatan kualitas hidup konsumen, pemasaran harus mempertimbangkan kebutuhan semua konsumen. Selain itu, pemasaran tidak dapat melepaskan diri dari isuisu utama yang membentuk masyarakat. Kegagalan untuk menyelidiki peran platform yang didukung teknologi dalam konteks masyarakat kita yang menua merupakan kesenjangan besar dalam penelitian. Kami berharap artikel ini akan mendorong para peneliti untuk mempertimbangkan area penting ini sebagai fokus penelitian.

\section{UCAPAN TERIMAKASIH}

Artikel ini dibuat berdasarkan PKM Kelompok Masyarakat Songkok Recca di Desa Paccing Kecamatan Awangpone Kabupaten Bone Universitas Terbuka dengan nomor kontrak 21564/UN31.LPPM/PM.01.01/2021. Skema PKM Dosen.

\section{DAFTAR RUJUKAN}

Al-Afifi, A. A. M., Yasmin, A., Tasneem, S., \& Fatema, K. (2015). international-journalof-management-science-and-businessadministration International Journal of Management Scie... Kathakali phouzder International Journal of Management Science and Business Administration Effectiveness of Digital Marketing in the Challe. International Journal of Management Science And Business Administration, 1(5), 69-80. Retrieved from

http://researchleap.com/category/internati onal-journal-of-management-scienceand-business-administration

Camilleri, M. (2020). Higher education marketing communications in the digital era. Strategic Marketing of Higher Education in Africa, 79-95. https://doi.org/10.4324/9780429320934-7

De Vries, L., Gensler, S., \& Leeflang, P. S. H. (2012). Popularity of Brand Posts on Brand Fan Pages: An Investigation of the Effects of Social Media Marketing. Journal of Interactive Marketing, 26(2), 83-91. https://doi.org/10.1016/j.intmar.2012.01.0 03

Diez-Martin, F., Blanco-Gonzalez, A., \& PradoRoman, C. (2019). Research challenges in digital marketing: Sustainability. Sustainability (Switzerland), 11(10). https://doi.org/10.3390/su11102839

Doshi, P. V. (2018). Study on Online Shopping 
Drives affecting Satisfaction of Users *. 3085(07), 172-176.

Dwityas, N. A., Mulyana, A., Hesti, S., Briandana, R., \& Kurniasari, P. M. (2020). Digital marketing communication strategies: The case of Indonesian news'portals. International Journal of Economics and Business Administration, 8(3), 307-316. https://doi.org/10.35808/ijeba/517

Goldfarb, A., McDevitt, R. C., Samila, S., \& Silverman, B. S. (2015). The effect of social interaction on economic transactions: Evidence from changes in two retail formats. Management Science, 61(12), 2963-2981. https://doi.org/10.1287/mnsc.2014.2030

Hair, J. F., Harrison, D. E., \& Risher, J. J. (2018). Marketing research in the 21st century: Opportunities and challenges. In Revista Brasileira de Marketing (Vol. 17). https://doi.org/10.5585/bjm.v17i5.4173

Kannan, P. K., \& Li, H. "Alice." (2017). Digital marketing: A framework, review and research agenda. International Journal of Research in Marketing, 34(1), 22-45. https://doi.org/10.1016/j.ijresmar.2016.11. 006

Katsikeas, C., Leonidou, L., \& Zeriti, A. (2020). Revisiting international marketing strategy in a digital era: Opportunities, challenges, and research directions. International Marketing Review, 37(3), 405-424. https://doi.org/10.1108/IMR-02-20190080

Kezer, M., Sevi, B., Cemalcilar, Z., \& Baruh, L. (2016). Age differences in privacy attitudes, literacy and privacy management on Facebook. Cyberpsychology, 10(1). https://doi.org/10.5817/CP2016-1-2

Kim, K.-I., Gollamudi, S. S., \& Steinhubl, S. (2017). Digital technology to enable aging in place. https://doi.org/10.1016/j.exger.2016.11.0 13

Kim, K. H., \& Moon, H. (2021). Innovative digital marketing management in B2B markets. Industrial Marketing Management, 95, 14.

https://doi.org/10.1016/j.indmarman.2021 .01 .016

Leeflang, P. S. H., Verhoef, P. C., Dahlström, P., \& Freundt, T. (2014). Challenges and solutions for marketing in a digital era. European Management Journal, 32(1), 112.

https://doi.org/10.1016/j.emj.2013.12.001

Marescotti, A., Quiñones-Ruiz, X. F., Edelmann, H., Belletti, G., Broscha, K.,
Altenbuchner, C., ... Scaramuzzi, S. (2020). Are protected geographical indications evolving due to environmentally related justifications? An analysis of amendments in the fruit and vegetable sector in the European union. Sustainability (Switzerland), 12(9). https://doi.org/10.3390/SU12093571

Mary C. Lacity, \& P.Willcocks, L. (2016). A New Approach to Automating Services. The Undergraduate Historical Journal at UC Merced, https://doi.org/10.5070/h331033416

Mogaji, E., Soetan, T. O., \& Kieu, T. A. (2021). The implications of artificial intelligence on the digital marketing of financial services to vulnerable customers. Australasian Marketing Journal, 29(3), 235-242. https://doi.org/10.1016/j.ausmj.2020.05.0 03

Muniraju, M., \& Bhojaraja. (2018). ISSN NO : 2394-8442 " Challenges and Opportunities in Digital Marketing " Keywords: laetsd Journal for Advanced Research in Applied Sciences, 5(1), 170172.

Olphert, W., \& Damodaran, L. (2013). E-Mail Regenerative and Technological Section / Viewpoint Older People and Digital Disengagement: A Fourth Digital Divide? Gerontology, 59, 564-570. https://doi.org/10.1159/000353630

Policy Brief: Human Rights - Internet Society. (n.d.). Retrieved November 11, 2021, from https://www.internetsociety.org/policybrief s/humanrights/

Quinn, K. (2021). Social media and social wellbeing in later life. Ageing and Society, 41(6), 1349-1370. https://doi.org/10.1017/S0144686X19001 570

Rose, S., Hair, N., \& Clark, M. (2011). Online Customer Experience: A Review of the Business-to-Consumer Online Purchase Context. International Journal of Management Reviews, 13(1), 24-39. https://doi.org/10.1111/J.14682370.2010.00280.X/FORMAT/PDF

Royle, J., \& Laing, A. (2014). The digital marketing skills gap: Developing a Digital Marketer Model for the communication industries. International Journal of Information Management, 34(2), 65-73. https://doi.org/10.1016/j.jijinfomgt.2013.11 .008

Sands, S., Harper, E., \& Ferraro, C. (2011). Customer-to-noncustomer interactions: Extending the "social" dimension of the store environment. Journal of Retailing and Consumer Services, 18(5), 438-447. 
https://doi.org/10.1016/j.jretconser.2011.0 6.007

Sharma, A., Sharma, S., \& Chaudhary, M. (2020). Are small travel agencies ready for digital marketing? Views of travel agency managers. Tourism Management, 79(February), 104078. https://doi.org/10.1016/j.tourman.2020.10 4078

Steinhoff, L., \& Palmatier, R. W. (2021). Commentary: Opportunities and challenges of technology in relationship marketing. Australasian Marketing Journal, $\quad 29(2), \quad 111-117$. https://doi.org/10.1016/j.ausmj.2020.07.0 03

Susilo, B. (2018). Pemasaran Digital: Segmentasi Demografi Pengguna Media Sosial di Kota Pontianak. Eksplora Informatika, 8(1), 69. https://doi.org/10.30864/eksplora.v8i1.16 3

Tristanto. (n.d.). Restaurants Look To Automation To Cut Labor, But Will Consumers Buy What The Drone Is Serving? Retrieved November 11, 2021 , from

https://www.forbes.com/sites/darrentrista no/2017/05/16/restaurants-look-toautomation-to-cut-labor-but-willconsumers-buy-what-the-drone-isserving/?sh=71fbef2b3039

Wijaya. Ni Putu, P. O. (2021). Digital Marketing education as a Strategy to Get New Opportunities: A Geographical Case Study on Indogarment MSMEs, Indonesia. 11(1), 740-745. https://doi.org/10.48047/rigeo.11.1.61

Zhang, E. M. (2010). Understanding the Acceptance of Mobile SMS Advertising among Young Chinese Consumers. Psychology \& Marketing, 30(6), 461-469. https://doi.org/10.1002/mar 